\title{
ANALISIS PENGARUH KUALITAS PELAYANAN DAN FASILITAS KESEHATAN TERHADAP KEPUASAN PASIEN PUSKESMAS
}

\author{
Th. A. Radito \\ STIE IEU Yogyakarta
}

\begin{abstract}
This study aimed to examine the effect of quality of service and health facilities owned by the health center (Puskesmas) to the patient's satisfaction. Puskesmas as the spearhead of health services in the community are expected to provide quality service and have adequate health facilities so as to increase patient satisfaction. This research was conducted at the Puskesmas Mantrijeron Jl. Panjaitan Mantrijeron 52 Yogyakarta. Puskesmas Mantrijeron chosen as the study site because it is a health center that organizes the quality of health services by government programs of Yogyakarta and by standards of the ISO (International Organization For Standardization) 9001: 2008.

Subjects were patients who had treatment and are being treated at the Puskesmas Mantrijeron during the past year. Data collected in the form of primary data derived from the questionnaire which distributed to each respondent. Methods of data analysis using multiple regression. The results showed that the quality of care and health facilities are significantly affects the increase in patient satisfaction. However, from the regression results indicate that the quality of service and health facilities was only able to explain of $39.1 \%$ patient satisfaction. While the remaining $60.9 \%$ is influenced by other factors.
\end{abstract}

Keywords: Satisfaction, quality of service, health facilities, Puskesmas

Pendahuluan

Latar Belakang Masalah

Puskesmas merupakan bentuk pelayanan dan fasilitas kesehatan yang penting dan terjangkau bagi seluruh kalangan masyarakat, khususnya bagi masyarakat ekonomi menengah ke bawah. Faktor biaya periksa dan obat yang lebih murah, serta lokasinya yang mudah dijangkau (berada di tiap kelurahan ataupun kecamatan) merupakan alasan utama masyarakat memilih Puskesmas sebagai tempat untuk berobat.

Puskesmas dijadikan ujung tombak pelayanan kesehatan dasar bagi masyarakat hal itu karena keberadaan Puskesmas yang menyebar ke semua daerah di setiap kelurahan, kecamatan, kabupaten. Keberadaan Puskesmas lebih dekat dengan masyarakat daripada Rumah Sakit. Di mana keberadaan Rumah sakit ditingkat kecamatan relatif sedikit, sebagian besar ditingkat kabupaten atau propinsi saja. Disamping itu biaya 
periksa, biaya obat relatif lebih murah dan prosedurnya lebih mudah di Puskesmas daripada di Rumah Sakit.

Tujuan utama dari program upaya pelayanan kesehatan bukan semata-mata untuk penyembuhan penyakit, tetapi lebih diarahkan untuk meningkatkan kemampuan fisik mental dan kehidupan sosial masyarakat, sehingga derajat kesehatan masyarakat semakin meningkat, dan sarana yang diharapkan mampu menjalankan fungsi ini salah satunya adalah Puskesmas (Khusnawati 2011).

Puskesmas disepakati sebagai suatu unit pelayanan kesehatan yang memberikan pelayanan kuratif dan preventif secara terpadu, menyeluruh dan mudah dijangkau, dalam wilayah kerja kecamatan atau sebagian kecamatan di kota madya atau kabupaten (Notoatmodjo, 2007). Pengertian Puskesmas menurut Pedoman Kerja Puskesmas DEPKES-RI adalah suatu kesatuan organisasi kesehatan fungsional yang merupakan pusat pengembangan kesehatan masyarakat yang juga membina peran serta masyarakat disamping memberikan pelayanan secara menyeluruh dan terpadu kepada masyarakat di wilayah kerjanya dalam bentuk kegiatan pokok.

Sejak diperkenalkannya Puskesmas pada tahun 1969, berbagai hasil telah banyak dicapai. Angka Kematian Ibu
(AKI) dan Angka Kematian Bayi (AKB) telah berhasil diturunkan. AKI telah dapat diturunkan dari 318 per 100.000 kelahiran hidup pada tahun 1997 menjadi 228 per 100.000 kelahiran hidup pada tahun 2007 (Survei Dep. Kes Indonesia, 2007). AKB telah dapat diturunkan dari 46 per 1.000 kelahiran hidup pada tahun 1997 menjadi 34 per 1.000 kelahiran hidup pada tahun 2007 (SDKI, 2007). Sejalan dengan penurunan AKB, Umur Harapan Hidup $(\mathrm{UHH})$ rata-rata bangsa Indonesia telah meningkat secara bermakna dari 68,6 (tahun 2004) menjadi 70,5 (tahun 2007) (Departemen Kesehatan 2007).

Di Yogyakarta sendiri hasil sensus penduduk sejak tahun 1971 sampai dengan sensus tahun 2010 menunjukkan bahwa terjadi penurunan yang sangat signifikan angka kematian bayi dari 102 bayi per 1000 kelahiran hidup sampai 17 bayi per 1000 kelahiran hidup pada tahun 2010 (sesuai hasil sensus penduduk). Sedangkan menurut proyeksi BPS (Badan Pusat Statistik) dari hasil sensus penduduk tahun 2000 pada kurun waktu 2000-2005 (5 tahun) penurunan AKB (Angka Kematian Bayi) rata-rata per tahun adalah 3,9\%. Sedangkan untuk periode tahun 2005 -2010 penurunan AKB rata-rata per tahun adalah $2,5 \%$ dan periode 2010 - 2015 adalah 1,7\%. Periode tahun 2020 - 2025 diperkirakan tidak terjadi penurunan karena tingkat kematian yang sudah sangat kecil 
("hardrock") yang dipengaruhi oleh faktor-faktor yang sangat sulit untuk dikendalikan diantaranya faktor genetik (Dinas Kesehatan Yogyakarta, 2012). Dengan hal tersebut sehingga pada tahun 2008 Provinsi DIY memperoleh penghargaan Manggala Bhakti Husada Kartika dari Presiden yaitu sebuah penghargaan atas prestasi sebagai propinsi dengan derajad kesehatan terbaik di Indonesia. Indikator yang dinilai paling peka dan telah disepakati secara nasional sebagai ukuran derajad kesehatan suatu wilayah meliputi : (1) Umur Harapan Hidup, (2) Angka Kematian Ibu, (3) Angka Kematian Bayi, (4) Angka Kematian Balita, dan (5) Status Gizi Balita / bayi (Dinas Kesehatan Yogyakarta 2012).

$\begin{array}{rlr}\text { Fungsi } & \text { Puskesmas dalam } \\ \text { memberikan } & \text { pelayanan kepada }\end{array}$
masyarakat dihadapkan pada beberapa tantangan dalam hal sumber daya manusia dan peralatan kesehatan yang semakin canggih, namun harus tetap memberikan pelayanan yang terbaik. Kemungkinan masih banyak pasien yang berobat ke Puskesmas, terutama di daerah-daerah yang masih minim sarana kesehatan. Hal ini kemungkinan disebabkan karena ( Khusnawati 2010) :

1. Biaya berobat di Puskesmas lebih murah, misalnya adanya jamkesos, jamkesmas, jamkesda.
2. Semakin banyak dokter yang bertugas di Puskesmas sehingga semakin banyak klinik dalam Puskesmas, semakin senang pula pasien yang berobat di Puskesmas.

3. Lokasi Puskesmas yang dekat dengan masyarakat dan mudah dijangkau.

4. Pengaruh kebijakan asuransi kesehatan dan kebijakan pemerintah.

Sekarang ini tercatat 7.669 unit Puskesmas, 22.171 Puskesmas pembantu, dan 6.392 Puskesmas keliling yang tersebar di seluruh Indonesia (Depkes RI, 2005). Sedangkan Puskesmas yang ada di DIY sendiri dapat kita lihat di tabel 1.

Dengan melihat jumlah sarana pelayanan kesehatan dasar di Indonesia maupun di setiap propinsi, maka Puskesmas diharapkan menjadi ujung tombak pelaksanaan pelayanan kesehatan di suatu daerah dan merupakan unit organisasi yang bersifat menyeluruh dan terpadu paling dekat dengan masyarakat. Peran dan fungsi Puskesmas sangat strategis dalam pembangunan kesehatan di Indonesia. Puskesmas berperan menyelenggarakan upaya kesehatan untuk meningkatkan kesadaran, kemauan, dan kemampuan hidup sehat bagi setiap penduduk agar memperoleh derajat kesehatan yang optimal (Depkes RI 2003). 
Jumlah Puskesmas di Propinsi D.I.Yogyakarta ada 121 Puskesmas yang tersebar di lima Kabupaten, 42 diantaranya dengan rawat inap dan 79 non rawat inap. Jumlah puskesmas terbanyak adalah di Kabupaten Gunungkidul dengan 30 Puskesmas disusul oleh Kabupaten Bantul dan Sleman masing-masing 27 dan 25 Puskesmas. Sementara untuk Kota Yogyakarta memiliki 18 puskesmas. Propinsi D.I.Y juga memiliki Puskesmas yang telah mendapatkan sertifikat sistem manajemen mutu ISO (International Organization For Standardization) 9001: 2008, hingga tahun 2012 tercatat 30 Puskesmas telah mendapatkan sertifikat ISO 9001:2008 yang tersebar di lima kabupaten di wilayah DIY di antaranya, 3 Puskesmas di Kota Yogyakarta, 1 Puskesmas di Bantul, 1 Puskesmas di Kulon Progo, 6 Puskesmas di Gunung Kidul dan 19 Puskesmas di Sleman (Dinkes Prov. DIY 2012).

Tabel 1. Sarana Pelayanan Kesehatan

Dasar di Provinsi DIYTahun 2012

\begin{tabular}{|c|c|c|c|c|c|c|}
\hline Kab/Kota & Puskesmas & Pusk TT & $\begin{array}{c}\text { Pusk Non } \\
\text { TT }\end{array}$ & Pustu & Polindes & $\begin{array}{c}\text { Pusk } \\
\text { tersertifikasi } \\
\text { ISO } \\
\end{array}$ \\
\hline Kota & 18 & 3 & 15 & 10 & 0 & 3 \\
\hline \multicolumn{7}{|l|}{ Yogyakarta } \\
\hline Bantul & 27 & 16 & 11 & 68 & 16 & 1 \\
\hline Gunung Kidul & 30 & 14 & 16 & 107 & 30 & 6 \\
\hline Kulon Progo & 21 & 5 & 16 & 62 & 40 & 1 \\
\hline Sleman & 25 & 4 & 21 & 71 & 86 & 19 \\
\hline PROVINSI & 121 & 42 & 79 & 318 & 172 & 30 \\
\hline
\end{tabular}

Sumber : Seksi Yankerdas 2012( Dinkes Provinsi DIY, 2012)

ISO 9001:2008 adalah suatu standar internasional untuk sistem manajemen Mutu / kualitas. ISO 9001:2008 menetapkan persyaratan - persyaratan dan rekomendasi untuk desain dan penilaian dari suatu sistem manajemen mutu. ISO 9001:2008 bukan merupakan standar produk, karena tidak menyatakan persyaratan - persyaratan yang harus dipenuhi oleh sebuah produk (barang atau jasa). ISO 9001:2008 hanya merupakan standar sistem manajemen kualitas. Namun, bagaimanapun juga diharapkan bahwa produk yang dihasilkan dari suatu sistem manajemen kualitas internasional, akan berkualitas baik (standar). Sehingga dapat disimpulkan bahwa Quality Management Systems (ISO 9001:2008) adalah merupakan prosedur terdokumentasi dan praktek - praktek standar untuk manajemen sistem, yang bertujuan menjamin kesesuaian dari suatu proses dan produk (barang atau jasa) terhadap kebutuhan atau persyaratan tertentu, dimana kebutuhan atau persyaratan tertentu tersebut ditentukan atau dispesifikasikan oleh pelanggan dan organisasi. Sertifikat ISO 9001:2008 
merupakan standar sistem manajemen mutu yang telah mendapatkan pengakuan dari banyak negara di dunia, seperti AS, Australia, China, India, Jepang dan negara-negara Eropa.

Manfaat Penerapan ISO 9001:2008 adalah :

\section{Meningkatkan}

kepercayaan pelanggan

2. Jaminan kualitas produk dan proses

3. Meningkatkan produktivitas perusahaan \& "market gain"

4. Meningkatkan motivasi, moral \& kinerja karyawan

5. Sebagai alat analisa kompetitor perusahaan

6. Meningkatkan hubungan saling menguntungkan dengan pemasok

7. Meningkatkan cost efficiency \& keamanan produk

8. Meningkatkan komunikasi internal

9. Meningkatkan image positif perusahaan

10. Sistem terdokumentasi

11. Media untuk pelatihan dan pendidikan

Seluruh Puskesmas di Kota Yogya ditargetkan meraih standar pelayanan ISO 9001:2008 dalam jangka waktu dua tahun ke depan. Pada tahun 2014 ditargetkan semua Puskesmas di Yogya berstandar ISO (International Organization for Standardization) 9001:2008. Saat ini dari 18 Puskesmas yang ada di Kota Yogya, baru tiga Puskesmas yang telah berstandar ISO 9001:2008, yakni Puskesmas Umbulharjo II, Mantrijeron dan Jetis. Pada tahun 2013, akan ditambah dua Puskesmas lagi untuk mendapatkan standar ISO 9001:2008, yakni Puskesmas Wirobrajan dan Umbulharjo I. Standar yang harus dipenuhi Puskesmas untuk mendapatkan ISO 9001:2008 menyangkut pelayanan medis, operasional sampai petugas front office yang kesehariannya berhubungan langsung dengan pendaftaran pasien. Standar ISO 9001:2008 dapat mengurangi komplain dari masyarakat (Dinas Kesehatan Yogyakarta, 2012).

Aksesibilitas jarak jangkauan terhadap sarana pelayanan kesehatan cukup merata antar kabupaten kota di Yogyakarta. Penduduk DIY di setiap Kabupaten / Kota pada umumnya berada pada kisaran 1-5 km terhadap Puskesmas. Sarana pelayanan kesehatan di Provinsi DIY relatif cukup banyak baik dari segi jumlah maupun jenisnya. Sarana pelayanan kesehatan dasar milik pemerintah (Puskesmas) telah menjangkau keseluruhan Kecamatan yang ada di Kabupaten / kota seluruh DIY bahkan jika digabungkan dengan puskesmas pembantu sebagai jaringan pelayannya, telah mampu menjangkau seluruh desa yang ada. Seluruh Puskesmas telah dilengkapi dengan jaringan Puskesmas Pembantu, Puskesmas Keliling dan memiliki jaringan 
kemitraan dengan Desa Siaga di seluruh wilayah. Perkembangan pelayanan kesehatan dasar di sektor swasta juga berkembang dengan pesat dengan munculnya berbagai sarana pelayanan seperti dokter praktek swasta, bidan praktek swasta, poliklinik, praktek bersama dan lainnya (Dinas Kesehatan Yogyakarta, 2012).

Tabel 2Peserta Jaminan Kesehatan Keluarga Miskin Propinsi DIYTahun 2012

\begin{tabular}{lrrrr}
\hline $\begin{array}{c}\text { WILAYAH } \\
\text { Kab/kota }\end{array}$ & JML JIWA & $\begin{array}{c}\text { JAMKES } \\
\text { MAS }\end{array}$ & JAMKESOS & \multicolumn{1}{c}{ JAMKESDA } \\
\hline KOTA YOGYA & 388.088 & 68.456 & 13.200 & 152.842 \\
BANTUL & 910.572 & 222.987 & 92.000 & 2.796 \\
K.PROG0 & 388.755 & 141.893 & 56.000 & 25.000 \\
G.KIDUL & 674.408 & 340.635 & 83.000 & 1.059 \\
SLEMAN & 1.090 .567 & 168.158 & 19.000 & 195.600 \\
JUMLAH & $\mathbf{3 . 4 5 2 . 3 9 0}$ & $\mathbf{9 4 2 . 1 2 9}$ & $\mathbf{2 6 3 . 2 0 0}$ & $\mathbf{3 7 7 . 2 9 7}$ \\
\hline
\end{tabular}

Sumber : BPS 2012, Dinkes Provinsi DIY 2012

Dengan melihat jumlah peserta jaminan kesehatan keluarga miskin di DIY (2012) seperti jamkesmas, jamkesos, jamkesda, tentunya pemerintah DIY memerlukan pelayanan kesehatan bagi masyarakat kurang mampu agar terpenuhi kebutuhan tentang kesehatannya. Keberadaan Puskesmas sekarang ini menyebar dan menyeluruh di semua daerah, bahkan sampai daerah yang minim akses sarana kesehatan lainnya. Puskesmas dijadikan tempat rujukan jaminan kesehatan bagi masyarakat kurang mampu dimana hal tersebut menjadi program pemerintah pusat sampai ke pemerintah daerah. Bencana alam yang menimbulkan kemiskinan bagi sebagian masyarakat pastilah memerlukan bantuan pelayanan kesehatan, maka berbagai daerah mengeluarkan kebijakan antara lain berobat gratis, jaminan kesehatan masyarakat dan lainnya.

Puskesmas merupakan fasilitas kesehatan yang penting dan terjangkau bagi seluruh kalangan masyarakat, khususnya bagi masyarakat ekonomi menengah ke bawah. Faktor biaya periksa dan obat yang lebih murah, serta lokasinya yang mudah dijangkau (berada di tiap kelurahan ataupun kecamatan) merupakan alasan utama masyarakat memilih Puskesmas sebagai tempat untuk berobat. Puskesmas sebagai unit organisasi penyedia pelayanan kesehatan, dihadapkan pada lingkungan yang semakin kompetitif dengan makin banyaknya balai pengobatan / poliklinik swasta. Perubahan yang terjadi di lingkungan eksternal dan internal Puskesmas menyebabkan Puskesmas harus mengubah paradigma bahwa bukan semata organisasi yang bersifat sosial. Upaya yang dilakukan oleh Puskesmas agar tetap berkembang adalah dengan meningkatkan pendapatan dari retribusi pasien. Untuk dapat meningkatkan jumlah pasien di Puskesmas di harapkan mampu memberi pelayanan optimal, dalam rangka meningkatkan kunjungan pasien ke Puskesmas maka Puskesmas harus mampu menampilkan dan 
memberikan pelayanan kesehatan yang berkualitas dan bermutu.

Ada beberapa hal yang memerlukan perubahan segera dalam pelayanan Puskesmas yang sebagian mendapatkan penilaian negatif di masyarakat, seperti kebiasaan dokter atau petugas yang datang terlambat sehingga pasien kerap antri berjam-jam. Realitas ini bisa terjadi di Puskesmas di pedesaan yang masih terbatas jumlah dokternya, namun tidak tertutup kemungkinan juga terjadi di perkotaan yang telah memiliki dokter cukup banyak. Puskesmas diharapkan menjadi institusi pelayanan kesehatan profesional, yakni berorientasi kepada mutu layanan yang kompeten, inovatif, berorientasi pada kebutuhan dan kepuasan pelanggan atau pasien. Dengan Puskesmas yang telah mendapatkan sertifikat ISO 9001:2008 diharapkan tidak akan terjadi pelayanan buruk kepada pasien Puskesmas (Harian Analisa News 2013).

Perkembangan tingkat pelayanan di puskesmas saat ini sangat dipengaruhi oleh sertifikasi ISO (International Organization for Standardization) 9001:2008. Untuk mengetahui standarisasi tingkat kelayakan sarana dan prasarana sebuah Puskesmas demi menciptakan kualitas Puskesmas yang baik, sehingga dapat meminimalkan standar pelayanan. Upaya meningkatkan akses masyarakat terhadap pelayanan kesehatan yang berkualitas, di antaranya meningkatkan akses terhadap pelayanan kesehatan dasar. Di sini peran Puskesmas dan jaringannya sebagai institusi yang menyelenggarakan pelayanan kesehatan di jenjang pertama yang terlibat langsung dengan masyarakat menjadi sangat penting. Puskesmas bertanggungjawab menyelenggarakan pembangunan kesehatan di wilayah kerjanya yaitu meningkatkan kesadaran, kemauan, dan kemampuan hidup sehat bagi setiap orang yang bertempat tinggal di wilayah kerjanya agar terwujudnya derajat kesehatan yang setinggi-tingginya.

Pendekatan kualitas pelayanan yang banyak dijadikan acuan dalam penelitian pemasaran adalah model Service Quality (servqual) yang dikembangkan oleh Parasuraman dan Zeithaml (2004). Terdapat lima determinan kualitas pelayanan antara lain meliputi Tangibles (penampilan fasilitas fisik, peralatan), Realiability (keandalan, kemampuan untuk melaksanakan jasa), Responsiveness (ketanggapan, kemauan untuk membantu pelanggan), Assurance (jaminan dan kepastian), Emphaty (perhatian pribadi, syarat untuk peduli) (Kotler, 2004). Kelima dimensi kualitas pelayanan tersebut kemungkinan akan memberikan kepuasan pasien bila Puskesmas selalu melayani sebaik mungkin terhadap pasien. 
Selain kualitas pelayanan, fasilitas atau sarana prasarana adalah merupakan salah satu faktor pendukung tercapainya tujuan perusahaan sebagai pelayanan perusahaan jasa kepada pengguna jasa. Istilah sarana dan prasarana sebenarnya sama dengan fasilitas, yang mana dapat diartikan dengan segala sesuatu (baik berupa fisik dan uang) yang dapat memudahkan dan melancarkan pelaksanaan suatu usaha.

Menurut Leebov, Vergare dan Scott (1990) yang juga ikut mempengaruhi kepuasan konsumen adalah fasilitas, kelengkapan fasilitas turut menentukan penilaian kepuasan pasien, misalnya fasilitas kesehatan baik sarana dan prasarana, tempat parkir, ruang tunggu yang nyaman dan ruang kamar rawat inap. Walaupun hal ini tidak vital menentukan penilaian kepuasan pasien, namun rumah sakit perlu memberikan perhatian pada fasilitas rumah sakit dalam penyusunan strategi untuk menarik konsumen.

Menurut Bowles (1998) fasilitas kesehatan umum yang lain juga ikut mempengaruhi kepuasan pasien seperti kualitas pelayanan berupa makanan dan minuman, privasi dan kunjungan. Fasilitas ini berupa bagaimana pelayanan terhadap pemenuhan kebutuhan pasien seperti makanan dan minuman yang disediakan dan privasi ruang tunggu sebagai sarana bagi orang-orang yang berkunjung di rumah sakit. Fasilitas ruang inap untuk pasien yang harus rawat juga mempengaruhi kepuasan pasien. Fasilitas ruang inap ini disediakan berdasarkan permintaan pasien mengenai ruang rawat inap yang dikehendakinya.

Macam dan jenis fasilitas kesehatan ini dapat dibedakan bermacam-macam menurut kegunaannya, namun bila dilihat secara garis besarnya saja dibedakan menjadi medis dan non medis. Fasilitas kesehatan yang termasuk medis seperti peralatan cek gigi, peralatan yang digunakan dokter untuk melayani ataupun mengobati pasien, peralatan operasi, dan lain-lain. Sedangkan yang tergolong non medis yang harus disediakan seperti peralatan perkantoran, perlengkapan pemadam kebakaran, tempat tunggu pasien, tempat sampah, parkir dan lain-lainnya (Wijono 2000).

Pelayanan yang bermutu, termasuk di dalamnya adalah pelayanan kesehatan merupakan suatu keharusan sehubungan dengan tuntutan dan kebutuhan masyarakat serta berlakunya Peraturan Pemerintah nomor : 8/1999 tentang Perlindungan Konsumen. Dimana perbaikan dan penyempurnaan peningkatan mutu pelayanan kesehatan harus dilakukan secara periodik melalui pendekatan Total Quality Management, bagi seluruh petugas kesehatan, mulai dari puncak pimpinan, baik sebagai pejabat struktural ataupun fungsional, 
sampai dengan petugas pelaksana terdepan dan selalu mengikuti pola perkembangan IPTEK Kedokteran dan Kesehatan.

Dengan melihat alasan-alasan di atas dimana Puskesmas dijadikan ujung tombak pelayanan kesehatan dasar bagi masyarakat hal itu karena keberadaan Puskesmas yang menyebar ke semua daerah di setiap kelurahan, kecamatan, kabupaten. Keberadaan Puskesmas lebih dekat dengan masyarakat daripada Rumah Sakit. Dimana keberadaan Rumah sakit ditingkat kecamatan relatif sedikit, sebagian besar ditingkat kabupaten atau propinsi saja. Disamping itu biaya periksa, biaya obat relatif lebih murah dan prosedurnya lebih mudah di Puskesmas daripada di Rumah Sakit. Dikarenakan pentingnya keberadaan Puskesmas di sekitar masyarakat, maka Puskesmas harus berusaha melayani masyarakat menurut standar pelayanan setingkat Puskesmas dengan sebaik mungkin.

\section{RUMUSAN MASALAH}

Dengan dasar tersebut di atas maka Pokok permasalahan yang ingin dikaji dalam penelitian ini adalah:

1. Apakah kualitas pelayanan berpengaruh terhadap kepuasan pasien Puskesmas?
2. Apakah fasilitas kesehatan berpengaruh terhadap kepuasan pasien Puskesmas?

\section{LANDASAN TEORI}

A. Kualitas Pelayanan
1) Pengertian Kualitas

Kualitas memiliki hubungan yang erat dengan kepuasan pelanggan. Kualitas memberikan suatu dorongan kepada pelanggan untuk menjalin ikatan hubungan yang kuat dengan perusahaan. Tentang pengertian atau definisi kualitas dapat berbeda makna bagi setiap orang, karena kualitas memiliki banyak kriteria dan sangat tergantung pada konteksnya.

Heizer \& Render mengemukakan bahwa kualitas adalah loyalitas bentuk dan karakteristik barang / jasa yang menunjukkan kemampuannya untuk memuaskan kebutuhan-kebutuhan pelanggan yang tampak jelas maupun yang tersembunyi. Kualitas dapat juga diartikan bagi para penyedia jasa sebagai sesuatu yang harus dikerjakan dengan baik. Keunggulan suatu produk jasa adalah tergantung dari keunikan serta kualitas yang diperlihatkan oleh jasa tersebut, apakah sudah sesuai dengan harapan dan keinginan pelanggan (Supranto, 2001). Kualitas adalah tingkat keunggulan yang diharapkan dan pengendalian atas tingkat keunggulan tersebut untuk memenuhi keinginan pelanggan (Wykof dalam Tjiptono 1997). 
2) Pengertian Pelayanan

Pelayanan merupakan suatu kegiatan atau urutan kegiatan yang terjadi dalam interaksi langsung antara seseorang dengan orang lain. Pelayanan merupakan proses pemenuhan kebutuhan melalui aktifitas orang lain secara langsung. Pelayanan bukan hanya memberikan pelayanan setelah penjualan sekaligus diimbangan dengan kualitas seluruh produk. Adapun pelayanan pelanggan adalah pelayanan kepada pemakai jasa dengan tujuan memberikan kepuasan seoptimal mungkin yang dilakukan secara langsung maupun tidak langsung.

Dalam Kamus Besar Bahasa Indonesia (2001) pelayanan diartikan sebagai usaha melayani orang lain. Menurut Supranto (2001) Pelayanan merupakan suatu kinerja penampilan, tidak berwujud dan cepat hilang, lebih dapat dirasakan daripada dimiliki, serta pelanggan lebih dapat berpartisipasi aktif dalam proses mengkonsumsi jasa tersebut. Gronroos (2007) menyatakan bahwa pelayanan adalah suatu aktivitas atau serangkaian aktivitas yang bersifat tidak kasat mata (tidak dapat diraba) yang terjadi sebagai akibat adanya interaksi antara konsumen dengan karyawan atau hal-hal lain yang disediakan oleh perusahaan pemberi pelayanan yang dimaksudkan untuk memecahkan permasalahan konsumen/pelanggan".

Kotler (2004) menyatakan bahwa pelayanan adalah setiap kegiatan atau manfaat yang dapat diberikan suatu pihak kepada pihak lainnya, yang pada dasarnya tidak berwujud dan tidak pula berakibat pemilihan sesuatu dan produksinya dapat atau tidak dapat dikaitkan dengan suatu produk fisik.

Berdasar definisi-definisi tersebut, maka dapat disimpulkan bahwa pelayanan merupakan suatu kegiatan yang berupa pemberian layanan atau melayani pihak-pihak yang membutuhkan guna memenuhi kebutuhannya. Di mana pelayanan ditujukan untuk mencapai kepuasan pelanggan yang ditandai oleh berkuranngnya keluhan dari konsumen.

3) Pengertian Kualitas Pelayanan

Gronroose (2007) menjelaskan mutu pelayanan berdasarkan manufaktur adalah kecocokan produk dengan spesialisasi desain. Sedangkan mutu berdasarkan produk adalah tingkat karakteristik produk yang dapat diukur. Menurut Scheneider \& White (2004) kualitas pelayanan memegang peranan penting dalam industri jasa. Pelanggan dalam hal ini pasien akan merasa puas jika mereka memperoleh pelayanan yang baik atau sesuai dengan yang diharapkan. 
Bahkan Brown (1991) memberikan penekanan bahwa kualitas pelayanan adalah sesuatu yang harus dikerjakan penyedia jasa dengan baik, dalam rangka meraih keunggulan bersaing, pelanggan akan mencari bukti dari kualitas jasa yang ditawarkan, dan mereka akan menyimpulkan tentang kualitas dari tempat, orang, peralatan, simbol, harga yang mereka rasakan.

Lovelock (1991) memberikan pengertian kualitas pelayanan sebagai tingkat kesempurnaan untuk memenuhi keinginan konsumen. Sedangkan menurut Parasuraman \& Zeithaml (2004) kualitas pelayanan merupakan perbandingan antara pelayanan yang dirasakan (persepsi) konsumen dengan kualitas pelayanan yang diharapkan konsumen. Jika kualitas pelayanan yang dirasakan sama atau melebihi kualitas pelayanan yang diharapkan, maka pelayanan dikatakan berkualitas dan memuaskan konsumen.

Persaingan yang semakin ketat akhir-akhir ini menuntut sebuah lembaga penyedia jasa/layanan untuk selalu memanjakan konsumen atau pelanggan dengan memberikan pelayanan terbaik. Para pelanggan akan mencari produk berupa barang atau jasa dari perusahaan yang dapat memberikan pelayanan yang terbaik kepadanya. Kualitas pelayanan merupakan komponen penting dalam persepsi konsumen, juga sangat penting

dalam pengaruhnya terhadap kepuasan konsumen. Semakin baik kualitas maka jasa yang diberikan maka akan semakin baik pula citra jasa tersebut dimata konsumen (Barlow, 2010). Cronin \& Tailor (1992) menyatakan bahwa kualitas pelayanan berpengaruh signifikan terhadap kepuasan konsumen.

Gronroose (2007) menyatakan kualitas pelayanan meliputi kualitas fungsi, kualitas teknis, kualitas outpun dan reputasi perusahaan. Kualitas fungsi menekankan bagaimana pelayanan dilaksanakan, terdiri dari : dimensi kontak dengan konsumen, sikap dan perilaku, hubungan internal, penampilan, kemudahan akses, dan service mindedness. Sedangkan kualitas teknis kualitas output yang dirasakan konsumen, meliputi harga, ketepatan waktu, kecepatan layanan, dan estetika output. Reputasi perusahaan dicerminkan oleh citra perusahaan dan reputasi di mata konsumen.

Dari definisi-definisi tersebut dapat disimpulkan bahwa kualitas pelayanan adalah tingkat keunggulan pelayanan yang dapat memenuhi keinginan konsumen/pelanggan yang diberikan oleh suatu organisasi yang dapat memuaskan konsumennya.

4) Dimensi Kualitas Pelayanan 
Menurut Zeithaml, Parasuraman \& Berry (2004) ada lima dimensi kualitas pelayanan yaitu:

a. Tangibles (bukti langsung), adalah wujud kenyataan secara fisik meliputi fasilitas fisik, perlengkapan, pegawai dan sarana komunikasi.

b. Reliability (kehandalan), yakni kemampuan memberikan pelayanan yang dijanjikan segera dan memuaskan.

c.Responsiveness (daya tanggap), yaitu keinginan para staf untuk membantu para pelanggan dan memberikan pelayanan dengan tanggap.

d. Assurance (jaminan), mencakup kemampuan,kesopanan dan sifat yang dipercaya yang dimiliki para staf, bebas dari bahaya, resiko atau keragu-raguan.

e. Emphaty (empati), adalah sikap memberikan perhatian penuh meliputi kemudahan dalam melakukan hubungan komunikasi yang baik dan memahami kebutuhan para pelanggan.

Dimensi kualitas yang dikemukakan oleh Zeithaml et.al (2004) tersebut berpengaruh pada harapan pelanggan dan kenyataan yang mereka terima. Jika kenyataannya pelanggan menerima pelayanan melebihi harapannya, maka pelanggan akan mengatakan pelayanannya berkualitas atau memuaskan dan jika kenyataannya pelanggan menerima pelayanan kurang atau sama dari harapannya, maka pelanggan akan mengatakan pelayanannya tidak berkualitas atau tidak memuaskan.

5) Pelayanan Kesehatan

Pelayanan kesehatan adalah setiap upaya yang diselenggarakan sendiri atau secara bersama-sama dalam suatu organisasi untuk memelihara dan meningkatkan kesejahteraan, mencegah dan menyembuhkan penyakit serta memulihkan kesehatan perseorangan, keluarga, kelompok ataupun masyarakat (Irwanashari 2010). Levey, Loomba \& Brown (1984) menyatakan bahwa yang dimaksud dengan pelayanan kesehatan ialah setiap upaya yang diselenggarakan sendiri atau secara bersama-sama dalam suatu organisasi untuk memelihara dan meningkatkan kesehatan, mencegah dan menyembuhkan penyakit serta memulihkan kesehatan perseorangan, keluarga, kelompok dan ataupun masyarakat.

Macam pelayanan kesehatan menurut Hodgetts dan Cascio (1983) dapat dibedakan menjadi medical services (pelayanan kedokteran) dan public health service (pelayanan kesehatan masyarakat). Pelayanan kesehatan yang termasuk dalam kelompok pelayanan kedokteran (medical 
services) ditandai dengan cara pengorganisasian yang dapat bersifat sendiri (solo practice) atau secara bersama-sama dalam satu organisasi (institution), tujuan utamanya untuk menyembuhkan penyakit dan memulihkan kesehatan, serta sasarannya terutama untuk perseorangan dan keluarga.

Pelayanan kesehatan yang termasuk dalam kelompok pelayanan kesehatan masyarakat (public health services) ditandai dengan cara pengorganisasian yang umumnya secara bersama-sama dalam satu organisasi, tujuan utamanya untuk memelihara dan meningkatkan kesehatan serta mencegah penyakit, serta sasarannya terutama untuk kelompok dan masyarakat. Menurut Azwar (1996) sarana pelayanan kedokteran yang diselenggarakan oleh pemerintah di Indonesia adalah Puskesmas, sebagai sarana kesehatan tingkat pertama. Sedangkan Rumah Sakit dengan berbagai jenjangnya, sebagai sarana pelayanan kesehatan tingkat kedua dan ketiga. Puskesmas disepakati sebagai suatu unit pelayanan kesehatan yang memberikan pelayanan kuratif dan preventif secara terpadu, menyeluruh dan mudah dijangkau, dalam wilayah kerja kecamatan atau sebagian kecamatan di kota madya atau kabupaten (Notoatmodjo 2007).
Pengertian Puskesmas menurut Pedoman Kerja Puskesmas DEPKES-RI adalah suatu kesatuan organisasi kesehatan fungsional yang merupakan pusat pengembangan kesehatan masyarakat yang juga membina peran serta masyarakat disamping memberikan pelayanan secara menyeluruh dan terpadu kepada masyarakat di wilayah kerjanya dalam bentuk kegiatan pokok. Puskesmas merupakan perangkat pemerintah daerah tingkat II, sehingga pembagian wilayah kerja Puskesmas ditentukan oleh Bupati/Walikota, dengan saran teknis dari kepala Dinas Kesehatan Kabupaten/Kota.

Pelayanan kesehatan yang diberikan Puskesmas adalah pelayanan kesehatan menyeluruh, meliputi Kuratif (pengobatan), Preventif (upaya pencegahan), promotif (peningkatan kesehatan), dan Rehabilitatif (pemulihan kesehatan). Puskesmas sendiri dibedakan berdasarkan strata. Stratifikasi Puskesmas dibedakan menjadi strata satu (puskesmas dengan prestasi sangat baik), strata dua (puskesmas dengan prestasi rata-rata atau standar), dan strata tiga (puskesmas dengan prestasi dibawah rata-rata)

Sekalipun pelayanan kedokteran berbeda dengan pelayanan kesehatan masyarakat, namun untuk dapat disebut sebagai suatu pelayanan kesehatan yang baik, keduanya harus memiliki berbagai persyaratan pokok. Azwar 
menyatakan bahwa syarat pokok yang dimaksud meliputi hal-hal sebagai berikut:

a. Tersedia dan

berkesinambungan

Artinya semua jenis pelayanan kesehatan yang dibutuhkan oleh masyarakat tidak sulit ditemukan, serta keberadaannya di masyarakat adalah pada setiap saat yang dibutuhkan.

b. Dapat diterima dan wajar

Artinya pelayanan kesehatan tersebut tidak bertentangan dengan keyakinan dan kepercayaan masyarakat. Pelayanan kesehatan yang bertentangan dengan adat istiadat, kebudayaan, keyakinan dan kepercayaan masyarakat, serta bersifat tidak wajar, bukanlah suatu pelayanan kesehatan yang baik.

c.Mudah dicapai

Pengertian ketercapaian yang dimaksud disini terutama dari sudut lokasi. Dengan demikian untuk dapat mewujudkan pelayanan kesehatan yang baik, maka pengaturan distribusi sarana kesehatan menjadi sangat penting. Pelayanan kesehatan yang terlalu terkonsentrasi di daerah perkotaan saja, dan sementara itu tidak ditemukan di daerah pedesaan, bukan pelayanan kesehatan yang baik.

d. Mudah dijangkau

Pengertian keterjangkauan yang dimaksudkan disini terutama dari sudut biaya. Untuk dapat mewujudkan keadaan yang seperti ini harus dapat diupayakan biaya pelayanan kesehatan tersebut sesuai dengan kemampuan ekonomi masyarakat. Pelayanan kesehatan yang mahal dan karena itu hanya mungkin dinikmati oleh sebagian kecil masyarakat saja, bukan pelayanan kesehatan yang baik.

\section{e. Bermutu}

Maksudnya adalah yang menunjuk pada tingkat kesempurnaan pelayanan kesehatan yang diselenggarakan, yang disatu pihak dapat memuaskan para pemakai jasa pelayanan, dan di pihak lain tata cara penyelenggaraannya sesuai dengan kode etik serta standar yang telah ditetapkan.

Wijono (2009) menambahkan bahwa pendekatan mutu paripurna yang berorientasi pada kepuasan pelanggan atau pasien menjadi strategi utama bagi organisasi pelayanan kesehatan di Indonesia, agar puskesmas tetap eksis ditengah persaingan global yang semakin ketat.

\section{B. Fasilitas Kesehatan}

Fasilitas atau sarana prasarana adalah merupakan salah satu faktor pendukung tercapainya tujuan perusahaan sebagai pelayanan perusahaan jasa kepada pengguna jasa. Istilah sarana dan prasarana sebenarnya sama dengan fasilitas, yang mana dapat diartikan dengan segala sesuatu (baik 
berupa fisik dan uang) yang dapat memudahkan dan melancarkan pelaksanaan suatu usaha.

Menurut Leebov, Vergare dan Scott (1990) yang juga ikut mempengaruhi kepuasan konsumen adalah fasilitas, kelengkapan fasilitas turut menentukan penilaian kepuasan pasien, misalnya fasilitas kesehatan baik sarana dan prasarana, tempat parkir, ruang tunggu yang nyaman dan ruang kamar rawat inap. Walaupun hal ini tidak vital menentukan penilaian kepuasan pasien, namun rumah sakit perlu memberikan perhatian pada fasilitas rumah sakit dalam penyusunan strategi untuk menarik konsumen.

Menurut Bowles (1998) fasilitas kesehatan umum yang lain juga ikut mempengaruhi kepuasan pasien seperti kualitas pelayanan berupa makanan dan minuman, privasi dan kunjungan. Fasilitas ini berupa bagaimana pelayanan terhadap pemenuhan kebutuhan pasien seperti makanan dan minuman yang disediakan dan privasi ruang tunggu sebagai sarana bagi orang-orang yang berkunjung di rumah sakit. Fasilitas ruang inap untuk pasien yang harus rawat juga mempengaruhi kepuasan pasien. Fasilitas ruang inap ini disediakan berdasarkan permintaan pasien mengenai ruang rawat inap yang dikehendakinya.

$$
\text { C. Kepuasan Pasien }
$$

Press (2002) mendefinisikan bahwa kepuasan pasien adalah sesuainya harapan pasien dengan perlakuan yang diterimanya selama dalam perawatan. Sedangkan Krowinski \& Steiber (1996) mendefinisikan kepuasan pasien adalah evaluasi yang positif dari dimensi pelayanan yang spesifik dan didasari pada harapan pasien dan pelayanan yang diberikan. Wisnton \& Sommers (1999) menyatakan bahwa kepuasan pasien adalah dasar suatu ukuran kualitas atau mutu pelayanan keperawatan dan merupakan alat yang dapat dipercaya dan sahih dalam menyusun perencanaan pelaksanaan dan penilaian pengelolaan fasilitas kesehatan.

Makna dari kepuasan pasien sebenarnya pada hakekatnya sama dengan kepuasan pelanggan, karena sama-sama dalam usaha memberikan rasa kepuasan kepada konsumen. Kottler (1994) menyatakan bahwa pengertian kepuasan pelanggan merupakan evaluasi purna beli dimana alternatif yang dipilih sekurang-kurangnya sama atau melampaui harapan pelanggan, kepuasan pelanggan akan timbul apabila hasil (outcome) memenuhi harapan pembeli. Kepuasan pelanggan didefinisikan oleh Kotler sebagai perasaan senang atau kecewa seorang pelanggan yang muncul setelah membandingkan antara persepsi terhadap kinerja (hasil) suatu produk dan harapan-harapannya. 
Hill, Roche, \& Allen (2007) mendefinisikan kepuasan pelanggan adalah respon pelanggan terhadap evaluasi ketidaksesuaian yang dirasakan antara harapan dan kinerja aktual produk dalam pemakaiannya. Kepuasan pelanggan merupakan evaluasi purna beli dimana alternative yang dipilih sekurangkurangnya sama atau melampaui harapan pelanggan, sedangkan ketidakpuasan timbul apabila, hasil tidak memenuhi harapan.

Memahami kebutuhan dan keinginan konsumen dalam hal ini pasien adalah hal penting yang mempengaruhi kepuasan pasien. Pasien yang puas merupakan aset yang sangat berharga karena apabila pasien puas mereka akan terus melakukan pemakain terhadap jasa pilihannya, tetapi jika pasien merasa tidak puas mereka akan memberitahukan dua kali lebih hebat kepada orang lain tentang pengalaman buruknya. Untuk menciptakan kepuasan pasien suatu puskesmas atau rumah sakit harus menciptakan dan mengelolah suatu sistem untuk memperoleh pasien yang lebih banyak dan kemampuan untuk mempertahankan pasiennya (William \& Steiber, 1996).

Dari berbagai pendapat diatas dapat disimpulkan bahwa kepuasan pasien adalah wujud suatu pelayanan kesehatan yang memenuhi kebutuhan dan permintaan pasien. Besarnya harapan pasien akan menentukan tingkat kepuasan pasien terhadap layanan yang diterimanya. Kepuasan seorang pasien terhadap pelayanan fasilitas kesehatan tidak terlepas dari apa yang diharapkan pasien.

Leebov et.al (1990) mengemukakan tiga macam kondisi kepuasan yang bisa dirasakan oleh konsumen berkaitan dengan perbandingan antara harapan dan kenyataan, yaitu jika harapan atau kebutuhan sama dengan layanan yang diberikan maka konsumen akan merasa puas. Kepuasan konsumen merupakan perbandingan antara harapan yang dimiliki konsumen dengan kenyataan yang diterima oleh konsumen yang mengalami kepuasan terhadap suatu produk atau jasa. Leebov et.al (1990) juga menyebutkan bahwa faktor-faktor yang mempengaruhi kepuasan konsumen adalah karakteristik produk, harga, pelayanan, maupun orang lain yang berkunjung di rumah sakit, fasilitas, image, desain visual, suasana, dan komunikasi.

Hal tersebut diperkuat oleh Barlow (2010) bahwa aspek-aspek yang mempengaruhi perasaan puas pada seseorang dipengaruhi oleh beberapa faktor, yaitu:

1. Sikap pendekatan staf pada pasien yaitu sikap staf terhadap pasien ketika pertama kali datang di rumah sakit. 
2. Kualitas perawatan yang diterima oleh pasien yaitu apa saja yang telah dilakukan oleh pemberi layanan kepada pasien, seberapa pelayanan perawatan yang berkaitan dengan proses kesembuhan penyakit yang diderita pasien dan kelangsungan perawatan pasien selama berada dirumah sakit.

3. Prosedur administrasi yaitu berkaitan dengan pelayanan administrasi pasien dimulai masuk rumah sakit selama perawatan berlangsung sampai keluar dari rumah sakit.

4. Waktu menunggu yaitu berkaitan dengan waktu yang diperbolehkan untuk berkunjung maupun untuk menjaga dari keluarga maupun orang lain dengan memperhatikan ruang tunggu yang memenuhi standarstandar rumah sakit antara lain: ruang tunggu yang nyaman, tenang, fasilitas yang memadai misalnya televisi, kursi, air minum dan sebagainya.

5. Fasilitas umum yang lain seperti kualitas pelayanan berupa makanan dan minuman, privasi dan kunjungan. Fasilitas ini berupa bagaimana pelayanan terhadap pemenuhan kebutuhan pasien seperti makanan dan minuman yang disediakan dan privasi ruang tunggu sebagai sarana bagi orangorang yang berkunjung di rumah sakit.

6. Fasilitas ruang inap untuk pasien yang harus rawat. Fasilitas ruang inap ini disediakan berdasarkan permintaan pasien mengenai ruang rawat inap yang dikehendakinya.

Berdasarkan uraian dari beberapa ahli tersebut di atas, maka dapat disimpulkan bahwa kepuasan pasien adalah perasaan senang, puas individu karena terpenuhinya harapan atau keinginan dalam menerima jasa pelayanan kesehatan. Kepuasan pasien atau konsumen berdasarkan teori-teori diatas tidak hanya dipengaruhi atas jasa yang dihasilkan oleh suatu Puskesmas semata, tetapi juga dipengaruhi oleh pelayanan yang diberikan oleh petugas Puskesmas baik dokter, petugas medis dan karyawan-karyawan lainnya.

D. Hipotesis

Berdasarkan tinjauan pustaka yang sudah diuraikan maka hipotesis dalam penelitian ini ada 2, yaitu:

1. Kualitas pelayanan berpengaruh terhadap kepuasan pasien Puskesmas.

2. Fasilitas kesehatan berpengaruh terhadap kepuasan pasien Puskesmas.

E. Model Penelitian

Untuk menguji pengaruh nilai pelanggan dan citra merek terhadap kepercayaan atas merek digunakan model yang terdapat dalam Gambar 3.1

Gambar 1. Model Penelitian 


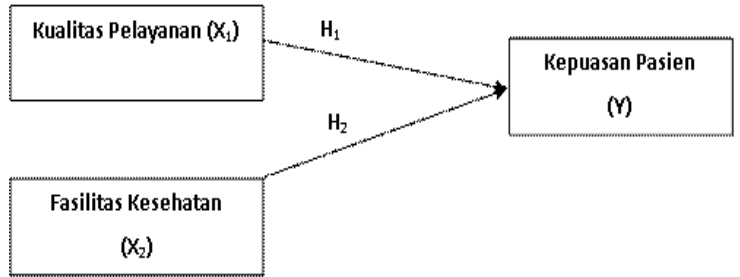

METODE PENELITIAN

A. Lokasi Penelitian

Penelitian ini dilakukan di Puskesmas Mantrijeron Jl. Panjaitan No.52 kecamatan Mantrijeron kota Yogyakarta. Puskesmas Mantrijeron dipilih sebagai lokasi penelitian karena salah satu Puskesmas yang menyelenggarakan kualitas pelayanan kesehatan berdasarkan program Pemerintah Daerah Istimewa Yogyakarta dan berstandar ISO (International Organization For Standardization) 9001:2008 di kota Yogyakarta. Puskesmas Mantrijeron telah mendapatkan berbagai penghargaan dari pemerintah antara lain Juara Citra kualitas pelayanan prima tahun 2010 , juara teladan tingkat kota tahun 2011, dan juara puskesmas terbaik tingkat Propinsi, Dokter gigi teladan, dan Gizi teladan tahun 2008. Dengan melihat hasil survei mutu kualitas pelayanan dan kinerja Puskesmas Mantrijeron yang bernilai baik pada tahun 2011, Puskesmas ini telah melakukan berbagai upaya untuk memberikan kualitas pelayanan terbaik kepada masyarakat. Penetapan sistem dan sarana prasana kesehatan terus dilakukan dalam memberikan kualitas kualitas pelayanan yang memuaskan pada masyarakat.

B. Data dan Teknik Pengumpulan

Data yang digunakan adalah data primer yang berasal dari pengisian kuesioner yang dibagikan kepada setiap responden. Data ini berkaitan dengan persepsi masing-masing responden mengenai pengaruh kualitas pelayanan dan fasilitas kesehatan terhadap kepuasan pasien puskesmas.

\section{Populasi dan Sampel Penelitian \\ Populasi dalam penelitian ini adalah} semua pasien Puskesmas Mantrijeron kecamatan Mantrijeron kota Yogyakarta. Jumlah sampel ditetapkan sebanyak 150 responden. Jumlah ini sudah memenuhi rules of thumbs yang dikemukakan oleh Roscoe (dalam Sekaran 2003), bahwa jumlah sampel yang tepat untuk sebagian besar penelitian adalah lebih dari 30 dan kurang dari 500. Metode sampling menggunakan purposive sampling atau sampel bertujuan yaitu sampel yang memiliki tujuan untuk memahami informasi tertentu pada sumber tertentu dengan memilih responden atas karakteristik relevan tertentu yang menggambarkan dimensi-dimensi (proporsi) populasi (Sekaran 2013). Kriteria purposive yang peneliti ambil sebagai sampel adalah pasien yang 
pernah berobat dan sedang berobat di Puskesmas Mantrijeron selama satu tahun terakhir.

D. Definisi Operasional Variabel

Definisi operasional adalah batasan pengertian variabel-variabel yang digunakan dalam penelitian. Definisi operasional diperlukan untuk menjelaskan supaya ada kesamaan penaksiran dan tidak mempunyai arti yang berbeda-beda (Sekaran 2003).

Kualitas Pelayanan

didefinisikan sebagai tingkat kesetujuan pasien terhadap kualitas pelayanan yang diberikan Puskesmas.

Fasilitas Kesehatan

didefinisikan sebagai tingkat kesetujuan pasien terhadap fasilitas kesehatan yang disediakan oleh Puskesmas.

Kepuasan Pasien (Y) didefinisikan tingkat kepuasan pasien terhadap kualitas pelayanan yang diberikan Puskesmas dan terhadap fasilitas kesehatan yang disediakan oleh Puskesmas.

\section{E. Pengukuran Variabel}

Pengukuran variabel dilakukan menggunakan skala Likert sebagai berikut:

1) Kategori Sangat Setuju : : 5

2) Kategori Setuju : : 4

3) Kategori Ragu-ragu : $\quad 3$

4) Kategori Tidak setuju : : 2

5) Kategori Sangat tidak Setuju : 1
F. Uji Instrumen Penelitian

1. Uji Validitas

Uji validitas dilakukan untuk mengetahui apakah suatu instrumen alat ukur telah menjalankan fungsi ukurnya. Menurut Sekaran (2003) validitas menunjukkan ketepatan dan kecermatan alat ukur dalam melakukan fungsi ukurnya. Untuk mengetahui konsistensi dan akurasi data yang dikumpulkan dari penggunaan instrumen dilakukan uji validitas dengan menggunakan analisis faktor (Confirmatory Factor Analysis/CFA). Analisis faktor adalah analisis statistik yang bertujuan untuk mereduksi dimensi data dengan cara menyatakan variabel asal sebagai kombinasi linear sejumlah faktor, sedemikian hingga sejumlah faktor tersebut mampu menjelaskan sebesar mungkin keragaman data yang dijelaskan oleh variabel asal. Sedangkan Confirmatory adalah mengkonfirmasi kesesuaian faktor. Sebagai alat bantu analisis tersebut digunakan program statistik SPSS for windows. Dalam uji validitas data seringkali digunakan analisis faktor dengan tujuan mengetahui faktor loading suatu item pertanyaan

\section{Uji Reliabilitas.}

Pengujian reliabilitas adalah berkaitan dengan masalah adanya kepercayaan terhadap instrumen. Suatu 
instrumen dapat memiliki tingkat kepercayaan yang tinggi (konsisten) jika hasil dari pengujian instrumen tersebut menunjukkan hasil yang tetap. Dengan demikian, masalah reliabilitas instrumen berhubungan dengan masalah ketepatan hasil. Uji reliabilitas dilakukan untuk mengetahui tingkat kestabilan suatu alat ukur. Pada penelitian ini, uji reliabilitas dilakukan dengan menggunakan pendekatan internal consistency reliability yang menggunakan Cronbach Alpha untuk mengidentifikasikan seberapa baik item-item dalam kuisioner berhubungan antara satu dengan yang lainnya. Sebuah faktor dinyatakan reliabel/handal jika koefisien Alpha lebih besar dari 0,6 (Sekaran 2003).

\section{HASIL DAN PEMBAHASAN}

A. Uji Instrumen Penelitian

Sebelum melakukan analisis data, data penelitian terlebih dahulu dilakukan uji validitas dan reliabilitas data penelitian. Uji validitas dalam penelitian ini menggunakan metode analisa faktor (Confirmatory Factor Analysis) sedangkan uji reliabilitas menggunakan cronbach alpha dengan alat bantu statistik SPSS.

\section{Uji Validitas}

Uji validitas dilakukan untuk mengetahui apakah suatu instrumen alat

ukur telah menjalankan fungsi ukurnya. Untuk mendapatkan koefisien validitas dilakukan dengan mengkorelasikan skor item total dari masing-masing atribut. Rumus yang digunakan dalam pengujian ini adalah CFA (Confirmatory Factor Analysis). Adapun hasil uji validitas yang telah dilakukan ditunjukan dalam tabel 3. Berdasarkan hasil uji validitas yang dilakukan terhadap butir-butir pertanyaan dari ketiga variabel penelitian tersebut secara keseluruhan butir pertanyaan adalah valid karena memiliki faktor loading $>0,4$ seperti yang disyaratkan masing-masing faktor loading di satu faktor, mengumpul menjadi satu tempat. Kualitas pelayanan terkumpul menjadi satu di faktor 2, fasilitas kesehatan terkumpul menjadi satu di faktor 3, kepuasan pasien terkumpul menjadi satu di faktor 1 .

Tabel 3. Rotated Component Matrixa 


\begin{tabular}{llll}
\hline & \multicolumn{3}{c}{ Component } \\
& \multicolumn{3}{c}{2} \\
\hline TP1 & .214 & .816 & .133 \\
TP2 & .211 & .833 & .139 \\
TP3 & .194 & .746 & .290 \\
TP4 & .112 & .741 & .382 \\
TP5 & .210 & .748 & .302 \\
FK1 & .239 & .273 & .749 \\
FK2 & .262 & .250 & .735 \\
FK3 & .176 & .176 & .669 \\
FK4 & .278 & .279 & .644 \\
FK5 & .278 & .192 & .792 \\
KP1 & .623 & .235 & .296 \\
KP2 & .710 & .194 & .269 \\
KP3 & .668 & .222 & .271 \\
KP4 & .768 & .103 & .168 \\
KP5 & .728 & .106 & .189 \\
KP6 & .694 & .180 & .207 \\
KP7 & .616 & .119 & .077 \\
\hline
\end{tabular}

Sumber: Data Primer Diolah 2014

2. Uji Reliabilitas

Tabel 4. Uji Reliabilitas Data

\begin{tabular}{|c|c|c|c|c|}
\hline Variabel & $\begin{array}{c}\text { Cronbach } \\
\text { alpha }\end{array}$ & $\begin{array}{l}\text { Kriteria } \\
\text { Nunnaly }\end{array}$ & $\begin{array}{c}\text { Hasil } \\
\text { Pengujian }\end{array}$ & Keterangan \\
\hline $\begin{array}{l}\text { Kualitas } \\
\text { pelayanan }\left(X_{1}\right)\end{array}$ & 0.893 & 0.60 & $\begin{array}{c}\text { Cronbach } \\
\text { Alpha }>0.60\end{array}$ & Reliabel \\
\hline $\begin{array}{l}\text { Fasilitas } \\
\text { Kesehatan }\left(X_{2}\right)\end{array}$ & 0.854 & 0.60 & $\begin{array}{c}\text { Cronbach } \\
\text { Alpha }>0.60\end{array}$ & Reliabel \\
\hline $\begin{array}{l}\text { Kepuasan } \\
\text { Pasien (Y) }\end{array}$ & 0.853 & 0.60 & $\begin{array}{c}\text { Cronbach } \\
\text { Alpha }>0.60\end{array}$ & Reliabel \\
\hline
\end{tabular}

Sumber: Data Primer, 2014

Pengujian reliabilitas adalah berkaitan dengan masalah adanya kepercayaan terhadap instrumen. Suatu instrumen dapat memiliki tingkat kepercayaan yang tinggi jika hasil dari pengujian instrumen tersebut menunjukkan hasil yang tetap. Dengan demikian, masalah reliabilitas instrumen berhubungan dengan masalah ketepatan hasil. Analisis reliabilitas penelitian ini menggunakan Cronbach Alpha untuk mengidentifikasikan seberapa baik itemitem dalam kuisioner berhubungan antara satu dengan yang lainnya. Berdasarkan uji reliabilitas menggunakan Cronbach Alpha, semua variabel yang dikumpulkan melalui instrumen penelitian adalah reliabel/handal karena Alpha lebih besar dari 0,6 .

B. Analisis data

Penelitian ini berdasarkan teori pendekatan kualitas pelayanan yang banyak dijadikan acuan dalam penelitian pemasaran yaitu model Service Quality (servqual) yang menyatakan bahwa kualitas pelayanan mempengaruhi kepuasan. Selain teori kualitas pelayanan di atas, fasilitas atau sarana prasarana adalah merupakan salah satu faktor memudahkan dan melancarkan pelaksanaan suatu usaha. Brown (1991) menyatakan bahwa fasilitas kesehatan mempengaruhi kepuasan konsumen/pasien.

TABEL 5. Regresi

\begin{tabular}{|c|c|c|c|c|c|c|}
\hline \multirow{2}{*}{\multicolumn{2}{|c|}{ Model }} & \multicolumn{2}{|c|}{$\begin{array}{l}\text { Unstandardized } \\
\text { Coefficients }\end{array}$} & \multirow{2}{*}{$\begin{array}{c}\text { Standardized } \\
\text { Coefficients } \\
\text { Beta }\end{array}$} & \multirow[b]{2}{*}{$t$} & \multirow[b]{2}{*}{ Sig. } \\
\hline & & B & Std. Error & & & \\
\hline \multirow[t]{3}{*}{1} & (Constant) & 6.487 & 2.029 & & 3.196 & .002 \\
\hline & $\mathrm{TP}$ & .239 & .092 & .210 & 2.602 & .010 \\
\hline & FK & .751 & .128 & .475 & 5.879 & .000 \\
\hline
\end{tabular}

a.Dependent Variable: KP 
Dengan alat uji Regresi Linear Berganda menggunakan SPSS maka di Tabel 5 didapatkan hasil bahwa kualitas pelayanan dan fasilitas kesehatan (variabel independen) berpengaruh terhadap kepuasan pasien (variabel dependen). Hal ini didukung dari hasil olah regresi yang menunjukkan bahwa nilai signifikan variabel kualitas pelayanan sebesar 0,010 dan variabel fasilitas kesehatan 0,000 yang sesuai syarat signifikan secara statistik $<0,050$. Dengan melihat hasil beta untuk kualitas pelayanan sebesar 0,210 dan fasilitas kesehatan sebesar 0,475 dapat disimpulkan bahwa fasilitas kesehatan lebih besar pengaruhnya dibandingkan kualitas pelayanan terhadap kepuasan pasien Puskesmas.

Hipotesis 1 menguji pengaruh kualitas pelayanan terhadap kepuasan pasien Puskesmas. Hipotesis 1 menyatakan bahwa kualitas pelayanan berpengaruh terhadap kepuasan pasien Puskesmas. Hasil regresi menunjukkan bahwa kualitas pelayanan berpengaruh terhadap kepuasan pasien, sehingga hipotesis 1 didukung.

Hipotesis 2 menguji pengaruh fasilitas kesehatan terhadap kepuasan pasien Puskesmas. Hipotesis 2 menyatakan bahwa fasilitas kesehatan berpengaruh terhadap kepuasan pasien Puskesmas. Hasil regresi menunjukkan bahwa fasilitas kesehatan berpengaruh terhadap kepuasan pasien, sehingga hipotesis 2 didukung.

\section{SIMPULAN}

Berdasarkan analisis data diperoleh kesimpulan bahwa dalam penelitian ini baik hipotesis 1 maupun hipotesis 2 didukung. Terdapat pengaruh positif yang signifikan kualitas pelayanan dan fasilitas kesehatan terhadap kepuasan pasien puskesmas. Hal ini berarti semakin tinggi kualitas pelayanan dan fasilitas kesehatan yang diberikan oleh pihak puskesmas maka akan semakin tinggi kepuasan para pasien yang berobat ke puskesmas. Hasil penelitian menunjukkan bahwa kualitas pelayanan dan fasilitas kesehatan berpengaruh terhadap kepuasan pasien. Nilai R Square sebesar 0,391 menunjukkan kedua faktor kualitas pelayanan dan fasilitas kesehatan memberi pengaruh sebesar 39,1\% sedangkan sisanya 60,9\% dipengaruhi oleh faktor-faktor lain. Ini berarti variabel independen bisa menjelaskan variabel dependen hanya sebesar 39,1\%, sedangkan 60,9\% dijelaskan oleh faktorfaktor lain. Kemungkinan faktor-faktor lain ini adalah : lokasi yang dekat dan mudah terjangkau, biaya berobat yang murah, keberadaan dokter/bidan, kecocokan dengan bidan dan obat Puskesmas, kualitas produk, mutu pelayanan keperawatan, persepsi pasien, 
ketrampilan perawat, komunikasi, sikap, ataupun harga, dan faktor emosional.

Saran untuk penelitian mendatang dapat memasukkan faktor-faktor kualitas produk, mutu pelayanan keperawatan, persepsi pasien, ketrampilan perawat, komunikasi, sikap, harga, service quality, emotional factor, lokasi yang dekat dan mudah terjangkau, biaya berobat yang murah, keberadaan dokter/bidan, kecocokan dengan bidan dan obat Puskesmas sebagai prediktor bagi kepuasan pasien.

Penggunaan metode purposive sampling dalam penelitian ini tidak memungkinkan hasil penelitian untuk digeneralisasikan. Maka supaya hasil penelitian dapat digeneralisasikan maka untuk penelitian selanjutnya disarankan pengambilan sampel menggunakan menggunakan simple random sampling.

\section{DAFTAR PUSTAKA}

Anief, Moh. (2008). Manajemen Farmasi.

Edisi kelima. Yogyakarta : Gajah Mada University Press.

Azwar, Azrul. (1996). Menuju Pelayanan Kesehatan Yang Lebih Bermutu. Yayasan Penerbitan Ikatan Dokter Indonesia.
Barlow, Janelle (2010). Branded Customer Service: The New Competitive Edge. ReadHowYouWant.com

Bawono, Anton. (2006). Multivariate Analysis Dengan SPSS. Cetakan Pertama.STAIN Salatiga Press.

Brown, Stephen Walter. 1991. Service Quality: Multidisciplinary and Multinational Perspectives. Lexington Books.

Cronin, J. Joseph, Jr. \& Taylor, Steven A. Josepth Cronin, Jr. \& Steven A. Tailor (1992). Measuring Service Quality: A Reexamination and Extension. Journal of Marketing. Vol. 56, No. 3 (Jul.,1992), pp. 55-68

Gronroose, Christian. 2007. Service Management and Marketing: Customer Management In Service Competition. 3rd Edition. Wiley.

Heizer, Jay H. and Render, Barry. (2001). Principles Of Operations Management. Prentice Hall.

Hill, Nigel., Roche, Greg. And Allen Rachel. 2007. Customer Satisfaction: The Customer Experience Through The Customer's Eyes. The Leadership Factor.

Hodgetts, RM., and Cascio, DM. 1983. Modern Health Care Management. New York. Academic Press, Inc.

Hurriyati, Ratih. (2005). Bauran Pemasaran dan Loyalitas. Bandung : Alfabeta. 
Indriantoro Dan Supomo. (1999). Metodologi Penelitian Bisnis. Yogyakarta: Penerbit BPFE.

Kotler, Philip. (2004). Marketing Insights From $\mathrm{A}$ to $\mathrm{Z}$ (Edisi I terjemahan Indonesia). Jakarta: Penerbit Erlangga.

Krowinski, William J. And Steiber, Steven R. 1996. Measuring And Managing Patient Satisfaction. Jossey Bass

Leebov, Wendy,. Vergare, Michael,. And Scott, Gail. 1990. Patient Satisfaction: A Guide To Practice Enhancement. Practice Management Information.

Levey, Samuel., Loomba, Narendra Paul, and Brown, Robert E. (1984). Health Care Administration: A Managerial Percpective. Lippincott.

Lovelock, Christopher H. 1991. Services Marketing. Prentice Hall.

Notoatmodjo, Soekidjo. (2007). Kesehatan Masyarakat Ilmu dan Seni Edisi Revisi. Jakarta: Penerbit PT Rineka Cipta.

Parasuraman, A \& Zeithaml, Valarie A. (2004). Service Quality. Marketing Science Institute.

Press, Irwin. 2002. Patient Satisfaction: Defining, Measuring, and Improving the Experience of Care. Health Administration Press.

Schneider, Benjamin \& White, Susan S. 2004. Service Quality: Research Perspective. SAGE Publications.
Sekaran, U. 2003. Research methods for business: A skill building approach. 4th Edition. John Wiley \& Sons, Inc.

Supranto. (2001). Pengukuran Tingkat Kepuasan Pelanggan. Jakarta : PT Rineka Cipta.

Tjiptono, Fandy. (1997). Strategi Pemasaran. Edisi Kedua. Cetakan Pertama. Yogyakarta: Penerbit Andi Offset.

Wijono, Djoko. (1999). Manajemen Mutu Pelayanan Kesehatan Teori Strategi dan Aplikasi. Surabaya : Airlangga University Press.

Winston, William. And Sommers, Paul A. (1999). Consumer Satisfaction in Medical Practice. 1st Edition. Routledge.

Zeithaml, Valarie., Bitner, Mary Jo, and Gremler, Dwayne. (2006). Services Marketing. McGraw-Hill Companies, Incorporated.

Zeithaml, Valarie., Parasuraman, A., and Berry, Leonard L. 1990. Delivering Quality Service: Balancing Customer Perceptions and Expectations. Simon and Schuster.

http://Www. Puskesmas di Banda Aceh Diharapkan Raih ISO. Harian Analisa.htm (Analisa/iranda novandi) Terbit Kamis, 07 Feb 2013 Diakses 5 Maret 2014

http://www. Analisis Kepuasan Pasien terhadap Pelayanan pada Puskesmas Sungai Durian, 
Kab.Kubu Raya ( Khusnawati, 2010)

Diakses 3 Maret 2014

http://www. ISO 9001 : 2008 ( Sistem

Manajemen Mutu ) berita oleh

Herubudiana Diakses 12 Maret 2014 http://www. Profil Puskesmas

Mantrijeron ( Dinas Kesehatan

Yogyakarta ) Diakses 12 Maret 2014

http://digg.com/d38MASV. Manajemen

sistem ISO 9001 : 2008. Diakses 12

Maret 2014

http://Www. Andreas Tri

Pamungkas/JIBI/Harian Jogja Edisi

Selasa, 26 Juni 2012 Diakses 5

Maret 2014.

http:/ /Www.Dinkes-Diy.Org,. Kesehatan

Daerah Istimewa Yogyakarta

2010.com Diakses 3 Maret 2014.

http:/ /Www.Dinkes-Diy.Org,. Kesehatan

Daerah Istimewa Yogyakarta

2012.com Diakses 5 Maret 2014.

http:/ /Www.Dinkes-Diy.Org,. Kesehatan

Daerah Istimewa Yogyakarta

2005.com Diakses 5 Maret 2014. 
Jurnal IImu manajemen. Volume 11, Nomor 2, April 2014 